\title{
Lack of allozyme and ISSR variation in the Rare endemic tree species, Berchemia berchemiaefolia (Rhamnaceae) in Korea
}

\author{
Seok-Woo LEE*, Yong-Mo KIM and Won-Woo KIM \\ Korea Forest Research Institute, 44-3 Omokchun-dong, Kwonsun-ku, Suwon 441-350, Republic of Korea
}

(Received 4 February 2002; accepted 24 June 2002)

\begin{abstract}
Rare plant species are commonly hypothesized to have little genetic variation because of genetic drift, strong and directional selection toward genetic uniformity in a limited number of environments, inbreeding depression and/or other factors. We investigated genetic variation in Berchemia berchemiafolia, a rare and endangered tree species worldwide, by examining 14 allozyme loci and 28 I-SSR amplicons in 111 individuals distributed among four populations in Korea. No allozyme and I-SSR variation were detected with the exception of one variant from one individual at Pgi-2 locus. A substantial genetic bottleneck accompanying the fluctuation of local population size caused by repeated human activities and inbreeding could account for this species' lack of genetic variation.
\end{abstract}

Berchemia berchemiaefolia / rare tree / no variation / allozyme / I-SSR

Résumé - Absence de variabilité d'allozyme et ISSR chez les espèces d'arbres rares et endémiques, Berchemia berchemiaefolia (Rhamnacée) en Corée. On fait en général l'hypothèse que les espèces rares ne disposent que d'une faible variabilité génétique pour différentes raisons : dérive génétique, forte sélection dans le sens de l'uniformité dans un nombre limité de milieux, dépression due à la consanguinité et divers autres facteurs. Nous avons étudié la variabilité génétique de Berchemia berchemiaefolia, espèce rare et en voie de disparition au niveau mondial, en examinant 14 loci d'allozyme et 281-SSR amplicon pour 111 individus provenant de quatre populations coréennes. Aucune variabilité d'allozyme et d'ISSR n'a pu être détectée à l'exception d'un variant chez un individu au locus Pgi-2. Ces modifications de taille des populations dues à des activités répétées se traduisent par un « goulot d'étranglement génétique » qui explique l'absence de variabilité génétique de l'espèce.

Berchemia berchemiaefolia / espèce ligneuse rare / absence de variabilité / allozyme ISSR (Inter simple sequence repeat)

\section{INTRODUCTION}

The genus of Berchemia (the family Rhamnaceae) includes 12-22 deciduous woody plants distributed in Asia, East Africa, and South America [10]. They are usually climbing or scandent plants, but rarely trees or shrubs growing as high as $6 \mathrm{~m}$. They have petiolated and pinnately many-veined leaves with small and caducous stipules. Small flowers have five sepals and five petals with fascicular inflorescence. Fruit is an elongate drupe and has leathery fleshy with one stone [10]. In Korea, the genus of Berchemia has only two native species [22]: B. racemosa Sieb. et Zucc., and B. berchemiaefolia (Makino) Koidz. The former one is a deciduous climber while $B$. berchemiaefolia is a deciduous small tree. The distribution of the two Berchemia species is quite limited. B. racemosa is known from only one population and B. berchemiaefolia is limited to 5-6 populations in Korea [22, 23].

B. berchemiaefolia was found in Korea in 1935 for the first time and since then it has been classified as a plant species endemic to Korea [12]. However, it also grows in the southern part of Japan and the middle part of China with very restricted distribution ranges [4, 11, 14]. In China, it is only found in Xingshan County, western Hubei, Shexian County (the Baizi Mountain) and Huoshan County, Anhui [4], while it occurs in Honshu, Shikoku, and Kyushu in Japan [11, 14]. In both countries, $B$. berchemiaefolia is designated as a rare and endangered tree species $[4,11]$ and is consequently considered endangered worldwide. On the other hand, some authorities classified $B$. berchemiaefolia as Rhamnella berchemiaefolia Makino, Chaydaia berchemiaefolia (Makino) Koidz, Berchemiella berchemiaefolia (Makino) Nakai, or Berchemiella wilsoni (Shneid.) Nakai [4, 11, 14]. Therefore, the species is of interest in studies of relationships between some genera of the tribe Zizipheae in the Rhamnaceae.

In Korea, B. berchemiaefolia usually grows mostly on the rocks in open forests at lower altitude, sometimes along the river valley $[12,22]$. It strongly demands light for early establishment. Bisexual flowers are yellow to greenish yellow in color and are produced from late June to early September. They are visited by insects, but there has been no study on their 
reproductive biology to determine whether $B$. berchemiaefolia is self-compatible or not. The fruit is found in small drupes about 7-8 $\mathrm{mm}$ long, turning from yellow to red in color when ripe. The fleshy pulp surrounds a kernel with one hard seed $[12,23]$. Seeds appear to be dispersed primarily by gravity and occasionally by floating [22].

After many years of allozyme surveys, some general patterns of genetic diversity in plants are beginning to emerge [6, 7]. However, so far, relatively few studies have examined patterns of genetic variation in rare plants compared to those for the plants with wide distribution ranges [13]. We might expect such species to maintain lower levels of variation than common plants do because of their more restricted population sizes and consequently their reduced opportunities for gene flow. They may also have experienced genetic drift because of founder effects and/or an enforced population bottleneck [13, 28].

The inter-simple sequence repeat (I-SSR) markers have recently become a popular tool in plant genetic studies $[5,9$, $25,27]$. The I-SSR technique can yield a large number of loci, thereby providing a more representative sample of the genome than is possible with allozymes. However, I-SSR also has some significant limitations. One of the most critical limitations for its use in genetic studies may be its dominant allelic expression. This characteristic precludes direct estimates of allelic frequencies from diploid materials and thus biases the estimates of genetic diversity and genetic differentiation as is in the case of RAPDs (Random Amplified Polymorphic DNAs) [21, 24].

The objectives of this study were (1) to examine genetic variation in $B$. berchemiaefolia throughout its range in Korea employing isozyme and I-SSR markers; and (2) to compare the results with previous reports for other rare plant species.

\section{MATERIALS AND METHODS}

\subsection{Plant materials}

From the late June to the mid-July of 2001, foliage tissues were collected from four natural stands located throughout the native range of B. berchemiaefolia in Korea (Fig. 1). Within each stand, over 30 (31-36) trees were selected for foliage collection with a minimum distance of $20 \mathrm{~m}$ in order to decrease the risk of relatedness. However, within a couple of stands, some trees were sampled in close proximity (within $20 \mathrm{~m}$ ) until the goal of 30 trees was reached. The leaves were placed in ice chests, and transported to the laboratory within $48 \mathrm{~h}$, where they were stored at $4{ }^{\circ} \mathrm{C}$ until needed.

\subsection{Enzyme extraction and allozyme procedure}

Enzymes were extracted between 1 and $7 \mathrm{~d}$ after collection. Leaves were cut finely, and crushed with a mortar and pestle in an extraction buffer. In preliminary trials, enzyme activity showed the best results in the Cheliak and Pitel [1] extraction buffer with some modifications. Then, enzyme extract was absorbed onto $4 \mathrm{~mm} \times$ $10 \mathrm{~mm}$ wicks cut from Whatmann $3 \mathrm{MM}$ chromatography paper, which were stored at $-70{ }^{\circ} \mathrm{C}$ until needed for analysis.

Using techniques of starch-gel electrophoresis based on Conkle et al. [2], 20 enzyme systems were surveyed in a preliminary test, and ten enzyme systems showing consistent and clear banding patterns were finally chosen: aspartate aminotransferase (AAT, E.C.2.6.1.1), glutamate dehydrogenase (GDH, E.C.1.4.1.2), glucose 6-phosphate

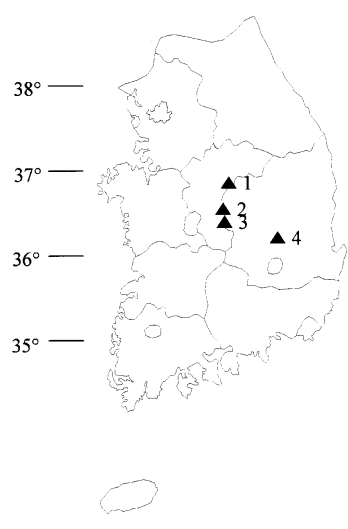

Figure 1. Locations of 4 sampled sites for Berchemia berchemiaefolia in Korea. 1: Wolak; 2: Sadam; 3: Seowon; 4: Juwang.

dehydrogenase (G6PD, E.C.1.1.1.49), isocitrate dehydrogenase (IDH, E.C.1.1.1.42), leucine aminopeptidase (LAP, E.C.3.4.11.1), malate dehydrogenase (MDH, E.C.1.1.1.37), phosphoglucose isomerase (PGI, E.C.5.3.1.9), phosphoglucomutase (PGM, E.C. 2.7.5.1), 6 phosphogluconate dehydrogenase (6PGD, E.C. 1.1.1.44) and shikimate dehydrogenase (SDH, E.C.1.1.1.25).

\subsection{DNA extraction and PCR amplification}

Total genomic DNA was extracted from foliages by a modified CTAB method [8]. PCRs (polymerase chain reactions) were carried out in a volume of $25 \mu \mathrm{L}$ with final concentrations of $5 \mathrm{ng}$ of template DNA; $0.2 \mathrm{mM}$ each of the four dNTPs; $0.025 \%$ BSA (Boeringer Manheim, Germany); $5 \mu \mathrm{L}$ of $1.5 \mu \mathrm{M}$ primer; $1.2 \mu \mathrm{L}$ of $25 \mathrm{mM}$ $\mathrm{MgCl}_{2}$ and 1 unit of Taq DNA polymerase (Advanced Biotechnique, UK). Amplifications were performed in a PTC-200 thermocycler (MJR Resaerch, USA) using a period of 5 min of initial denaturation at $94{ }^{\circ} \mathrm{C}$, followed by 45 cycles of $30 \mathrm{~s}$ of denaturation at $94{ }^{\circ} \mathrm{C}, 30 \mathrm{~s}$ annealing at $52{ }^{\circ} \mathrm{C}, 1 \mathrm{~min}$ of extension at $72{ }^{\circ} \mathrm{C}$, and a final extension step of 10 min at $72{ }^{\circ} \mathrm{C}$. Subsequent amplification products were electrophoresed using $2 \%$ agarose gels containing ethidium bromide fluorescence with a $1 \times \mathrm{TBE}$ (tris-boric acid-ethylendiamine tetraacetic acid) buffer at $\mathrm{pH} 8.0$ for $3.5 \mathrm{~h}$ and then photographed under UV light.

A total of 20 primers (UBC, Canada) were screened using three representatives from each of the four populations. Four primers that gave clear and reproducible fragment patterns over multiple (at least four) amplifications were selected for final analysis: UBC\#808 (AGAGAGAGAGAGAGAGC), UBC\#826 (ACACACACACACACACC), UBC\#829 (TGTGTGTGTGTGTGTGC), and UBC\#834 (AGAGAGAGAGAGAGAG(CT)T).

\section{RESULTS}

\subsection{Allozymes}

We detected no allozyme variation among any of the plants or populations with the exception of one individual from the Seowon population at $P g i-2$ locus. The leaves of the 111 plants were analyzed and all isozymes except PGI were monomorphic. One Pgi-2 variant appeared to be a heterozygote (Fig. 2). It was not possible to confirm patterns of inheritance for the enzymes studied owing to the lack of controlled-cross of fullsib progenies as well as to the lack of enzyme variability. Consequently, the number of loci and alleles were interpreted by drawing on the experience gained in our laboratory from 
studies of other angiosperm tree species and on the known subunit structures and cellular compartimentalization of the enzyme [29]. We conservatively estimated the number of genes encoding the 10 enzymes screened to be 14 .

\subsection{I-SSRs}

A total of 28 I-SSR amplicons, amplified with 4 I-SSR primers [UBC\#808 (6 amplicons), UBC\#826 (6 amplicons), UBC\#829 (6 amplicons), and UBC\#834 (10 amplicons)], were scored. As in the case of allozymes, none of the amplicons showed polymorphism (Fig. 3).

\section{DISCUSSION}

Rare endemic plant species are commonly hypothesized to have little genetic variation because of changes in allelic frequencies caused by chance events (small population size, founder effect or bottleneck effect), strong and directional selection toward genetic uniformity in a limited number of environments, inbreeding and/or other factors [13, 28].

In fact, according to Karron [13], most of the 24 rare plant species reviewed revealed low to moderate levels of genetic diversity. Likewise, Hamrick and Godt [6] reported that, of the four geographic range categories (endemic, narrow, regional, and widespread), endemic species had the lowest levels of genetic variation: endemic species (100 endemic taxa among the 480 species reviewed) had less than $50 \%$ of the genetic diversity of widespread species and 70 and $64 \%$ of the genetic diversity of narrowly and regionally distributed species. This trend has been confirmed in other studies [16, 18, 20], although there are exceptions $[13,17,19]$. On the other hand, only a few studies have reported a complete absence of genetic variability for rare and/or very locally distributed plant species. The narrow endemic Torrey pine (Pinus torreyana) displayed no variation among 59 loci within each of two populations, and alleles at only five loci differed between the populations [15], despite the fact that pines generally show high levels of isozyme variation. In contrast to Pinus torreyana, red pine $(P$. resinosa) is widely distributed throughout much of the northeastern United States and adjacent regions in Canada, but is also remarkably uniform with respect to both allozymes and RAPDs [3, 26]. This situation is attributed to Pleistocene glaciation, which appears to have reduced red pine to a small area and eliminated variation. Another rare plant species with no genetic polymorphism is Pedicularis furbishiae, which is restricted to the St. John River valley in northern Maine of the United States [28]. No allozyme variation appeared at 22 loci in 28 individuals.

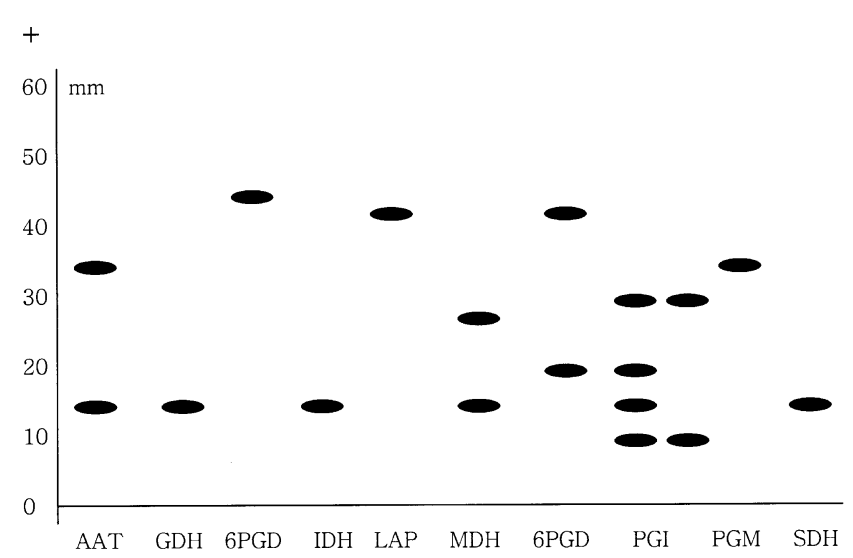

Figure 2. Phenotypes for 10 isozymes of Berchemia bercheniaefolia .

In Korea, $B$. berchemiaefolia has been severely disturbed by anthropogenic activities such as massive collection because it has been used as a traditional medicine, and its wood has been harvested to make furniture and handicraft or as fuel. Additionally, its distribution in farmland areas has promoted anthropogenic disturbances. These factors might have reduced $B$. berchemiaefolia to a small area and eliminated genetic variation through bottlenecks. Besides, some management activities might have negative impacts on $B$. berchemiaefolia. Foremost among these may be a high-grading cutting, in which the most valuable trees are removed and inferior trees are left to reproduce. Centuries of such dysgenic selection might reduce the gene pools of $B$. berchemiaefolia because whenever some trees are left after harvest to regenerate the stand, diversity of their offspring may be affected. In other words, if only a few trees are left to serve as seed parents, then inbreeding and its depression of viability are likely to take place. A study reported an evidence to support this hypothesis. According to Lee [22], most of B. berchemiaefolia trees in a natural stand produced empty seeds. Inbreeding depression reduces fitness and vigor in terms of survival, growth, and fertility by increased homozygosity of deleterious recessive allele as a result of inbreeding in a normally outbreeding population. More detailed studies on the reproductive biology and inbreeding depression in $B$. berchemiaefolia are needed, because a recent study showed that even self-fertile species can reveal dramatic levels of inbreeding depression [13].

We have no idea of whether the present range of $B$. berchemiaefolia corresponds to its past distribution. $B$. berchemiaefolia has difficulties in regeneration in a natural stand [12, 22, 23]. It requires light for its early establishment.

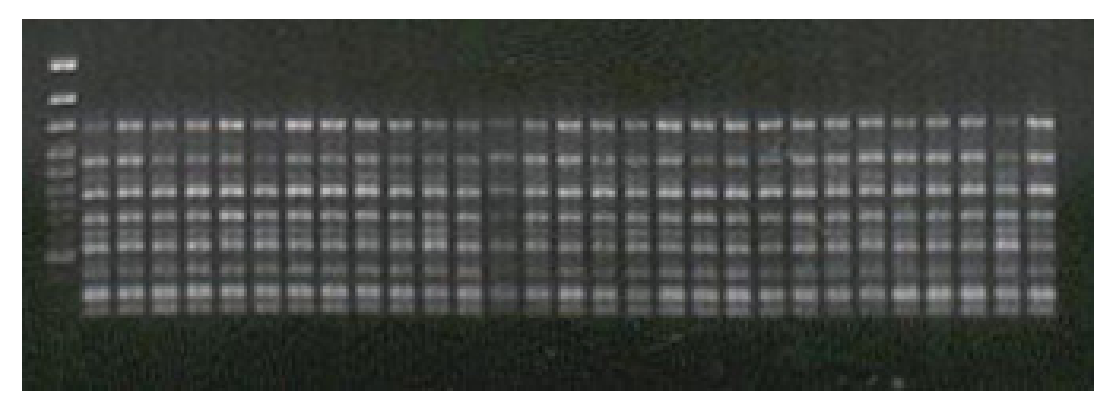

Figure 3. Example of I-SSR profiles (UBC\#834 primer) of Berchemia berchemiaefolia. Size markers (left-hand lanes) are fragments of 100-bp ladder (MBI Fermentas). 
Consequently, seedlings can be found only in the margin of a forest and/or within a gap in a closed forest. Besides, most seedlings do not develop into mature trees. According to Kang et al. [12], of 8655000 seeds/ha/yr of B. berchemiaefolia, only 406000 seeds developed into seedlings. Of these seedlings, 630 individuals grew into saplings and finally only 4 individuals developed into mature trees. These results may be, at least partially, connected with the inbreeding depression as discussed above. Accordingly, It is likely that B. berchemiaefolia has never occupied a large range owing to its ecological and reproductive traits. As a consequence, a substantial genetic bottleneck, combined with the fluctuation of local population sizes due to human activities, as well as local inbreeding could account for this species' lack of genetic variation. For a better understanding of the issue mentioned above, further studies are needed in the near future using highly variable molecular markers such as AFLPs.

In Korea, one natural population (Sadam population in the present study) and two old trees of $B$. berchemiafolia are legally protected as natural living monuments. However, most populations including the legally protected area are not currently regenerated by seeds. Most individuals are regenerated by the sprouts from the trunk of logged trees. Accordingly sprouting appears to be a main factor in B. berchemiaefolia's survival and maintenance in a natural habitat. So more active management such as partial clearing of vegetation to make gaps in a forest is needed to regenerate $B$. berchemiaefolia by seeds and to increase the population size in a more efficient way. Taking its rarity into account, we need to extend the legally protected areas, to give it legal protection against reckless collection, and/or to establish an ex situ conservation stand.

Acknowledgements: The authors thank two anonymous reviewers for helpful criticisms, and Y.P. Hong for helpful comments and advice on ISSR electrophoresis.

\section{REFERENCES}

[1] Cheliak W.M., Pitel J.A., Genetic control of allozyme variants in mature tissues of white spruce trees, Journal of Heredity 75 (1984) 34-40.

[2] Conkle M.T., Hodgskiss P.D., Nunnally L.B., Hunter S.C., Starch Gel Electrophoresis of Pine Seed: A Laboratory Manual, USDA Forest Service General Technical Report PSW-64, Pacific Southwest Forest and Range Experiment Station, Berkeley, California, USA, 1982.

[3] Fowler D.P., Morris R.W., Genetic diversity in red pine: Evidence for low genetic heterogeneity, Can. J. For. Res. 7 (1977) 343-347.

[4] Fu L.K. (Ed.), China Plant Red Data Book - Rare and Endangered Plants, Vol. 1, Science Press, Beijing, China, 1992.

[5] Godwin I.D., Aitken E.A.B., Smith L.W., Application of inter simple sequence repeat (ISSR) markers to plant genetics, Electrophoresis 18 (1997) 1524-1528.

[6] Hamrick J.L., Godt M.J.W., Allozyme diversity in plant species, in: Brown A.H.D., Clegg M.T., Kahler A.L., Weir B.S. (Eds.), Plant Population Genetics, Breeding, and Genetic Resources, Sinauer, Sunderland, Massachusetts, USA, 1989, pp. 43-63.

[7] Hamrick J.L., Godt M.J.W., Sherman-Broyles S.L., Factors influencing levels of genetic diversity in woody plant species, New Forests 6 (1992) 95-124.

[8] Hong Y.P., Hipkins V.D., Strauss S.H., Chloroplast DNA diversity among trees, populations and species in the California closed-cone pine (Pinus radiata, $P$. muricata and $P$. attenuata), Genetics 135 (1993) 1187-1196.
[9] Hong Y.P., Cho K.J., Kim Y.Y., Shin E.M., Pyo S.K., Diversity of I-SSR variants in the populations of Torreya nucifera, J. Korean For. Soc. 89 (2000) 167-172.

[10] Huxley A. (Ed.), The New Royal Horticultural Society Dictionary of Gardening, Macmillan Reference Ltd., New York, USA, 1992.

[11] Iwatsuki K., Boufford D.E., Ohba H. (Eds.), Flora of Japan, Vol. IIc, Kodansha Ltd., Tpkyo, Japan, 1999.

[12] Kang S.J., Kim H.E., Lee C.S., Ecological studies on the distribution, structure and maintenance mechanism of Berchemia berchemiaefolia forest, Korean J. Ecol. 14 (1991) 25-38 (in Korean with English summary).

[13] Karron J.D., Patterns of genetic variation and breeding systems in rare plant species, in: Falk D.A., Holsinger K.E. (Eds.), Genetics and Conservation of Rare Plants, Oxford University Press, New York, USA, 1991, pp. 87-98.

[14] Kitamura S., Murata G., Colored Illustrations of Woody Plants of Japan, Vol. 1, Revised edition, Hoikusha Publishing Co., Ltd., Osaka, Japan, 1994 (in Japanese).

[15] Ledig F.T., Conkle M.T., Genetic diversity and genetic structure in a narrow endemic, Torrey pine (Pinus torreyana Parry ex Carr.), Evolution 37 (1983) 79-85.

[16] Ledig F.T., Conkle M.T., Bermejo-Velázquez B., Eguiluz-Piedra T., Hodgskiss P.D., Johnson D.R., Dvorak W.S., Evidence for an extreme bottleneck in a rare Mexican pinyon: Genetic diversity, disequilibrium, and the mating system in Pinus maximartinezii, Evolution 53 (1999) 91-99.

[17] Ledig F.T., Capó-Artega M.A., Hodgskiss P.D., Sbay H., FloresLópez C., Conkle M.T., and Bermejo-Velázquez B., Genetic diversity and the mating system of a rare Mexican pinon, Pinus pinceana, and a comparison with Pinus maximartinezii (Pinaceae), Am. J. Bot. 88 (2001) 1977-1987.

[18] Lee S.W., Kim S.C., Lee H.S., Allozyme variation in Abeliophyllum distichum Nakai, an endemic tree species of Korea, Silvae Genetica 47 (1998) 294-298.

[19] Lee S.W., Kim C.S., Cho K.J., Choi W.W., Genetic variation in the endemic rare tree species, Empetrum nigrum var. japonicum K. Koch, Korean J. Breed. 29 (1997) 376-381 (in Korean with English summary).

[20] Lee S.W., Kim S.C., Kim W.W., Han S.D., Yim K.B., Characteristics of leaf morphology, vegetation and genetic variation in the endemic populations of a rare tree species, Koelreuteria paniculata Laxm, Jour. Korean For. Soc. 86 (1997) 167-176 (in Korean with English summary).

[21] Lee S.W., Ledig F.T., Johnson D.R., Genetic variation at allozyme and RAPD markers in Pinus longaeva (Pinaceae) of the White Mountains, California, American Journal of Botany 89 (2002) 566-577.

[22] Lee T.B., Distribution of Berchemia berchemiaefolia and an investigation for its conservation in Korea, Korean Journal of Plant Taxonomy 9 (1979) 1-6 (in Korean with English summary).

[23] Lee Y.M., Lee W.Y., Illustrated Rare and Endangered Species in Korea, Korea Forest Research Institute, Korea Forest Service, 1997 (in Korean).

[24] Lynch M., Milligan B.G., Analysis of population genetic structure with RAPD markers, Molecular Ecology 3 (1994) 91-99.

[25] Parsons B.J., Newbury H.J., Jackson M.T., Ford Lloyd B.V., Contrasting genetic diversity relationships are revealed in rice (Oryza sativa L.) using different marker types, Molecular Breeding 3 (1997) 115-125.

[26] Mosseler A., Egger K.N., Hughes G.A., 1992. Low levels of genetic diversity in red pine confirmed by random amplified polymorphic DNA markers, Can. J. For. Res. 22 (1992) 1332-1337.

[27] Tsumura Y., Ohba K., Strauss S.H., Diversity and inheritance of inter-simple sequence repeat polymorphisms in Douglas-fir (Pseudotauga menziesii) and sugi (Cryptomeria japonica), Theor. Appl. Genet. 92 (1996) 40-45.

[28] Waller D.M., O’Malley D.M., Gawler S.C., Genetic variation in the extreme endemic Pedicularis furbishiae (Scrophulariaceae), Conservation Biology 1 (1987) 335-340.

[29] Weeden N.F., Wendel J.F., Genetics of plant isozymes, in: Soltis D.E., Soltis P.S. (Eds.), Isozymes in Plant Biology, Discorides Press, Portland, Oregon, 1989, pp. 46-72. 